Article

\title{
Fluid Inclusion Characteristics of the Kışladağ Porphyry Au Deposit, Western Turkey
}

\author{
Nurullah Hanilçi ${ }^{1, *}$, Gülcan Bozkaya ${ }^{2}$, David A. Banks ${ }^{3}$, Ömer Bozkaya ${ }^{2}{ }^{\oplus}$, \\ Vsevolod Prokofiev ${ }^{4}$ (D) and Yücel Öztaş ${ }^{5}$ \\ 1 Department of Geological Engineering, Istanbul University-Cerrahpaşa, Avcılar, 34320 Istanbul, Turkey \\ 2 Department of Geological Engineering, Pamukkale University, 20070 Denizli, Turkey; \\ gbozkaya@pau.edu.tr (G.B.); obozkaya@pau.edu.tr (Ö.B.) \\ 3 School of Earth and Environment, University of Leeds, Leeds LS2 9JT, UK; D.A.Banks@leeds.ac.uk \\ 4 Institute of Geology of Ore Deposits, Petrography, Mineralogy and Geochemistry, Russian Academy of \\ Sciences, 119017 Moscow, Russia; vpr2004@rambler.ru \\ 5 TÜPRAG Metal Madencilik, Ovacık Mevki Gümüşkol Köyü, Ulubey Merkez, 64902 Uşak, Turkey; \\ yucelo@kisladag.com \\ * Correspondence: nurullah@istanbul.edu.tr; Tel.: +90-212-473-7070
}

Received: 17 November 2019; Accepted: 10 January 2020; Published: 13 January 2020

\begin{abstract}
The deposit occurs in a mid-Miocene monzonite magmatic complex represented by three different intrusions, namely Intrusion 1 (INT\#1), Intrusion 2 (INT\#2, INT \#2A), and Intrusion 3 (INT\#3). Gold mineralization is hosted in all intrusions, but INT\#1 is the best mineralized body followed by INT\#2. SEM-CL imaging has identified two different veins (V1 and V2) and four distinct generations of quartz formation in the different intrusions. These are: (i) CL-light gray, mosaic-equigranular quartz (Q1), (ii) CL-gray or CL-bright quartz (Q2) that dissolved and was overgrown on Q1, (iii) CL-dark and CL-gray growth zoned quartz (Q3), and (iv) CL-dark or CL-gray micro-fracture quartz fillings (Q4). Fluid inclusion studies show that the gold-hosted early phase Q1 quartz of V1 and V2 veins in INT\#1 and INT\#2 was precipitated at high temperatures (between 424 and $594{ }^{\circ} \mathrm{C}$ ). The coexisting and similar ranges of $\mathrm{T}_{\mathrm{h}}$ values of vapor-rich (low salinity, from $1 \%$ to $7 \% \mathrm{NaCl}$ equiv.) and halite-bearing (high salinity: $>30 \% \mathrm{NaCl}$ ) fluid inclusions in Q1 indicates that the magmatic fluid had separated into vapor and high salinity liquid along the appropriate isotherm. Fluid inclusions in Q2 quartz in INT\#1 and INT\#2 were trapped at lower temperatures between 303 and $380^{\circ} \mathrm{C}$ and had lower salinities between $3 \%$ and $20 \% \mathrm{NaCl}$ equiv. The zoned Q3 quartz accompanied by pyrite in V2 veins of both INT\#2 and INT\#3 precipitated at temperatures between 310 and $373^{\circ} \mathrm{C}$ with a salinity range from $5.4 \%$ to $10 \% \mathrm{NaCl}$ eq. The latest generation of fracture filling Q4 quartz, cuts the earlier generations with fluid inclusion $\mathrm{T}_{\mathrm{h}}$ temperature range from 257 to $333^{\circ} \mathrm{C}$ and salinity range from $3 \%$ to $12.5 \% \mathrm{NaCl}$ equiv. The low salinity and low formation temperature of $\mathrm{Q} 4$ may be due to the mixing of meteoric water with the hydrothermal system, or late-stage epithermal overprinting. The separation of the magmatic fluid into vapor and aqueous saline pairs in the Q1 quartz of the V1 vein of the INT\#1 and INT\#2 and $\mathrm{CO}_{2}$-poor fluids indicates the shallow formation of the Kışladağ porphyry gold deposit.
\end{abstract}

Keywords: SEM-CL imaging; fluid inclusion; porphyry Au deposit; Kışladağ; Turkey

\section{Introduction}

Turkey is located on the western portion of the Tethyan Metallogenic Belt (TMB), which extends from Europe through Turkey to Pakistan, Tibet, China, and South Asia (e.g., [1,2]). The principal geological features and formation of the metallogenic belts of Turkey were controlled by the evolution 
of the Neotethyan Ocean. Closure of the Neotethyan Ocean in eastern Turkey resulted in a continent-continent collision during the Miocene (e.g., [3,4]), while active continental subduction continued in western Turkey. An extensional tectonic regime was developed in the latest Oligocene-early Miocene (e.g., [5,6]), late Miocene (e.g., [7-9]), or early Pliocene onwards (e.g., [10]), that was responsible for magmatism and volcano-sedimentary basin development in western Anatolia (e.g., [11] and references therein). In western Anatolia, the Eocene to Miocene magmatism produced numerous porphyry intrusion-related hydrothermal deposits [12] within three main porphyry belts: in the Biga, Tavşanlı, and Afyon-Konya regions. The Kışladağ porphyry Au deposit, the subject of this study, is located in the Afyon-Konya porphyry belt (Figure 1).

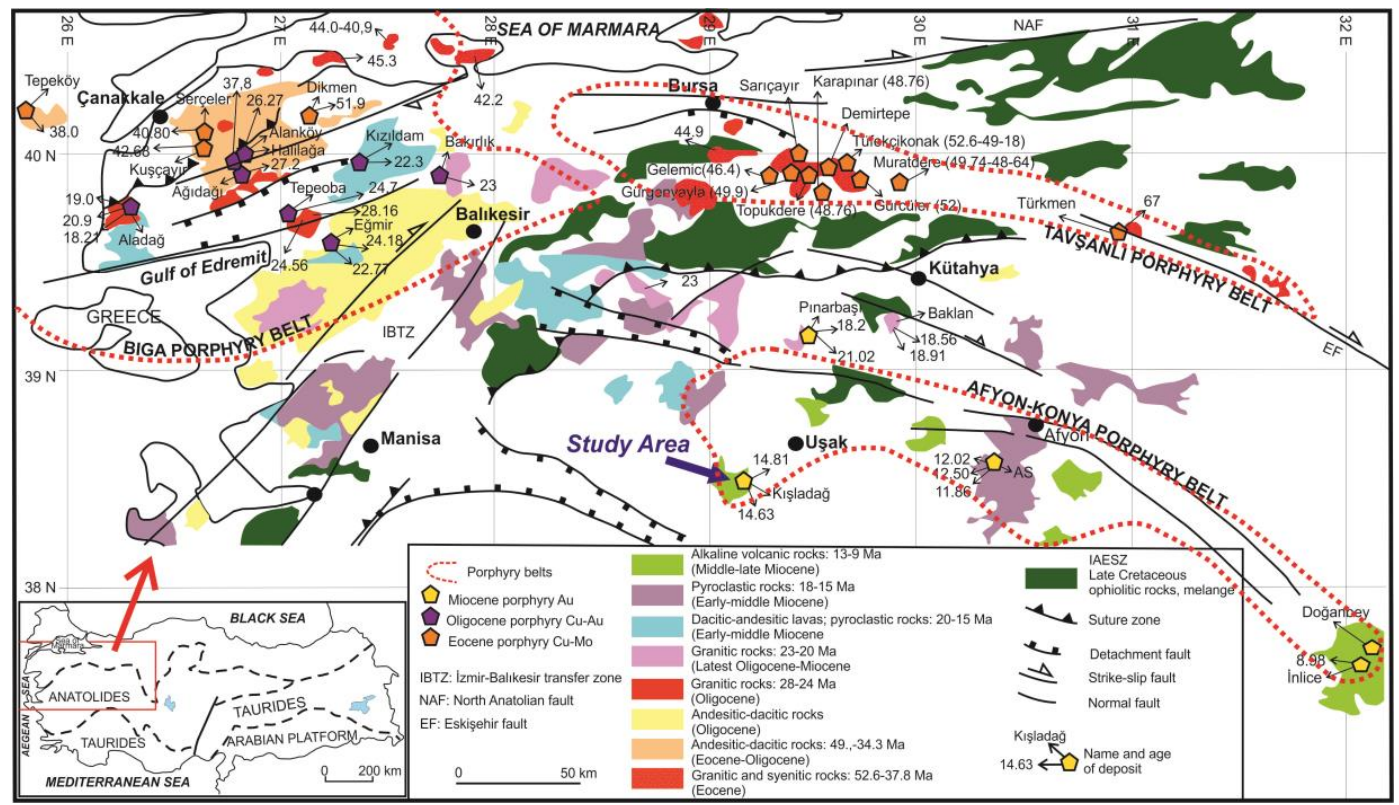

Figure 1. Simplified regional geological map of western Anatolia (location shown in the inset) showing Eocene to Miocene magmatic rocks and porphyry ore deposit belts (simplified from [12]).

The Kışladağ gold deposit is Europe's largest producing mine with different stages of mineralization occurring in the monzonite porphyry. The deposit consists of porphyry-style gold mineralization connected with a series of overlapping sub-volcanic monzonite intrusions in one of the several mid-to-late Tertiary volcanic complexes in western Turkey. Approximately 2.94 million ounces (Moz) of $\mathrm{Au}$ was produced between 2006 and 2018. It was reported that the deposit had 8.8 Moz Au (456 Mt of ore with ca. $0.61 \mathrm{~g} / \mathrm{t} \mathrm{Au}$ ) of measured and indicated resources at the end of 2018, with an inferred resource of 4.2 Moz Au (290 Mt ore with ca. $0.45 \mathrm{~g} / \mathrm{t} \mathrm{Au}$, using $0.35 \mathrm{~g} / \mathrm{t}$ Au cut off) [13]. The geological features of the Kışladağ deposit were studied in detail by [14] and classified as a gold-only porphyry deposit due to the absence of significant $\mathrm{Cu}$ mineralization, i.e., a low $\mathrm{Cu} / \mathrm{Au}$ ratio of $\sim 0.03$. In this study, the objective was to investigate the characteristics of fluid inclusions in hydrothermal quartz from different stages in the three intrusions. Scanning electron microscopy-cathodoluminescence (SEM-CL) imaging was used to establish the context of the fluid inclusion types that are present in the different vein generations. Therefore, the formation history of the quartz veins and the characteristics of the fluid inclusions they host, related to the porphyry gold formation, are well constrained.

\section{Geological and Lithological Features}

The Kışladağ Au deposit is located approximately $55 \mathrm{~km}$ southwest of Uşak (Figure 1), in western Turkey, and was the first porphyry-type gold mineralization discovered in Turkey. Due to the extensional tectonic regime in western Anatolia, the early-to-late Tertiary volcanic complexes (Elmadağ, İteciktepe, and Beydağı stratovolcanoes) outcrop close to Uşak (Figure 2; [11]). These 
stratovolcanoes occur in a NE-SW direction and have been dated between 17.29 Ma and 12.15 Ma by ${ }^{40} \mathrm{Ar} /{ }^{39} \mathrm{Ar}$ geochronology $[15,16]$. The Kışladağ porphyry Au deposit is related to monzonite intrusive and sub-volcanic rocks of the Beydağ1 volcanic complex with domes and intrusive bodies including andesites, latites, trachytes, dacites, rhyodacites, and rare basalts intruded into the pre-Cretaceous Menderes metamorphic rocks [11,14].

The main mineralized rocks of the deposit are alkali intrusions [17]. These are all monzonites, on the basis of their mineralogical and chemical compositions, and have been subdivided according to crosscutting relationships [14], alteration, and mineralization. These are (i) Intrusion 1 (INT\#1), (ii) Intrusion 2 (INT\#2), a more intense clay altered equivalent of Intrusion 2 (INT\#2A), and (iii) Intrusion 3 (INT\#3). All intrusions are mineralized but the most economic gold mineralization occurs within INT\#1, INT\#2, and INT\#2A (Figure 3). These intrusions intruded into a metamorphic basement (the Menderes metamorphics) and the older Beydağ1 volcanics.

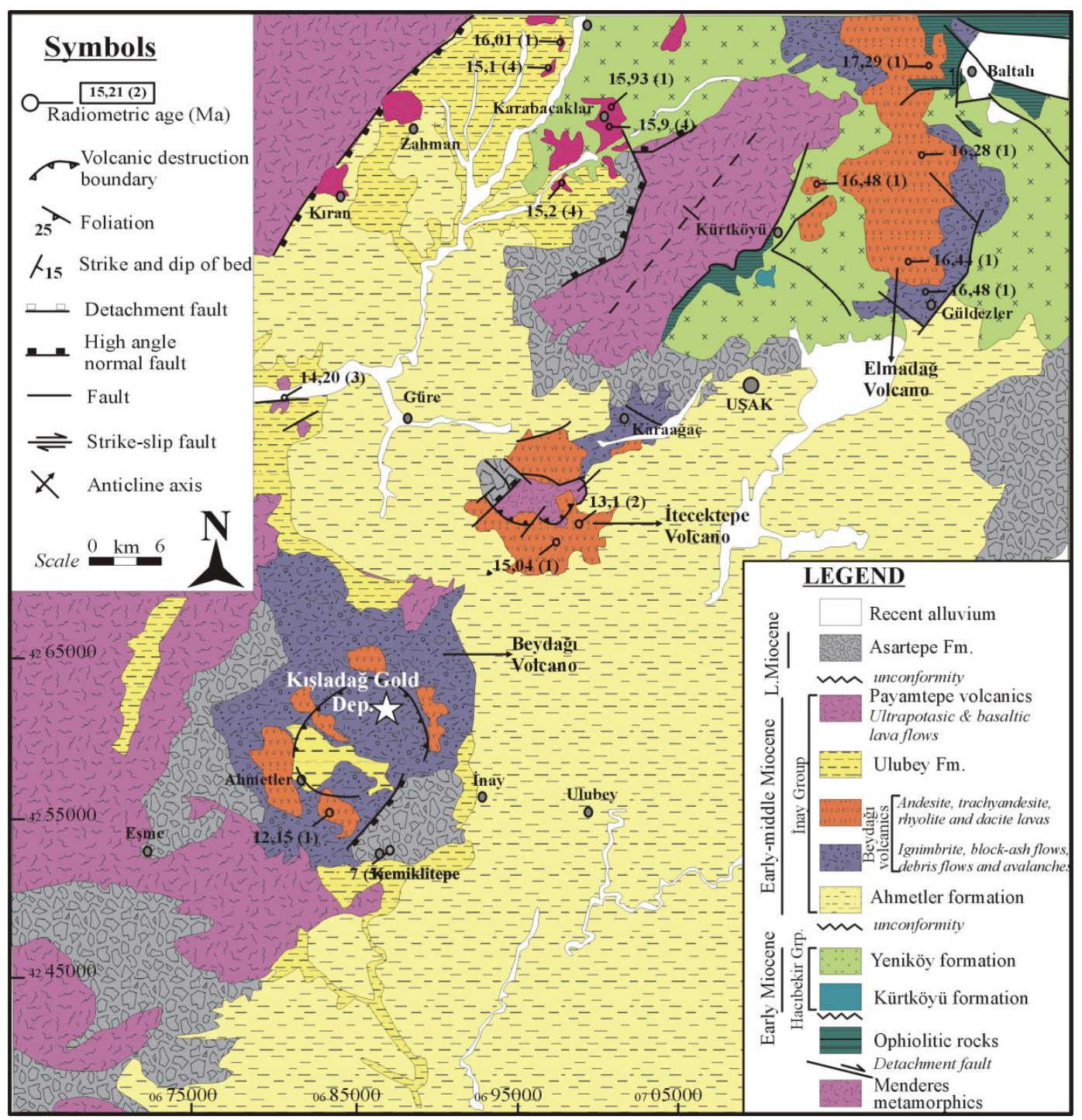

Figure 2. Geological map of the Uşak area [11] and location of the Kışladağ gold deposit. 


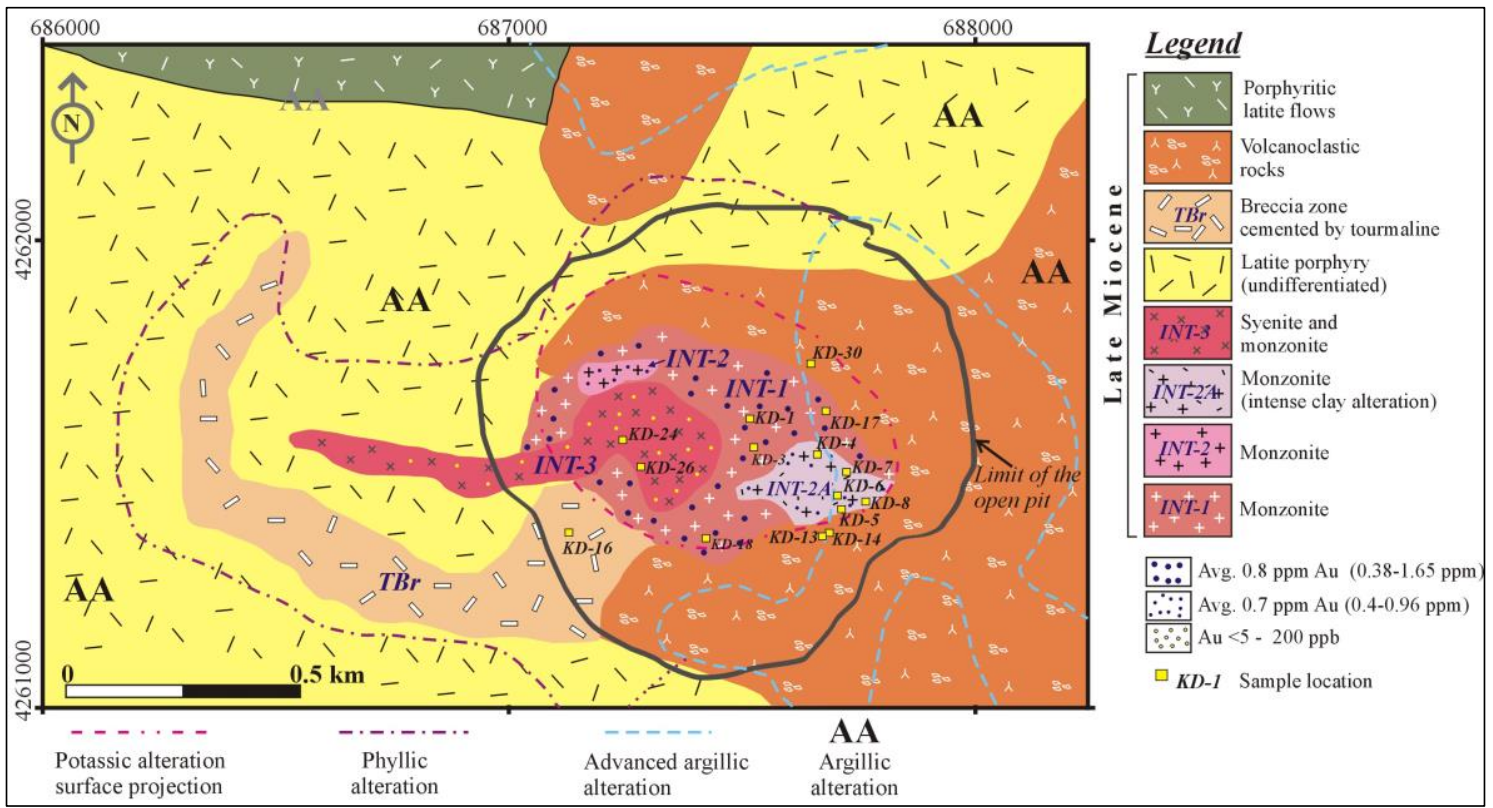

Figure 3. Lithological map of the Kışladağ Au deposit (modified after [17]; Au grades from [14]).

\subsection{Metamorphic Basement}

The metamorphic basement, represented by rocks of the Menderes Massif, is not exposed in the open pit but outcrops in the vicinity of the deposit, and has been intersected in the deep drill holes. It is composed of biotite-rich mafic schists to quartz-bearing schists [14]. The schist is composed mainly of quartz, plagioclase (albite), and white mica and contains quartz veins that have been affected by intense deformation. In the vicinity of the open pit, the foliation has a low dip angle to the south-east, elsewhere it is dominantly flat-lying, but may show a rapid transition to a steeply dipping configuration [15].

\subsection{Intrusive Rocks}

\subsubsection{Intrusion 1 (INT\#1)}

The intrusive rocks that host the Kışladağ Au deposit have been identified as INT\#1, INT\#2 (including INT\#2 and INT\#2A), and INT\#3, in chronological order according to the relationship observed both at the surface and in drill core data [14,17]. INT\#1 is the oldest and best mineralized intrusive phase in the Kışladağ mine area and forms the core of the system (Figure 3). INT\#1 comprises abundant phenocrysts of K-feldspar (Figures $4 \mathrm{a}$ and $5 \mathrm{a}$ ), plagioclase (30\% of the rock by volume), and biotite as the second most abundant phenocryst phase (up to $10 \%$ of the rock by volume). Blocky megacryst(s) of K-feldspar up to $1 \mathrm{~cm}$ are characteristic of this unit, but are not as common as quartz phenocrysts $[14,17]$. INT\#1 has been classified in the monzonite field according to the primary mineral assemblages [14]. INT\#1 is cross-cut by the younger porphyritic intrusions, and contacts between INT\#1 and the surrounding volcanic rocks are generally obscured by alteration. However, contact with INT\#3 is better preserved [14]. INT\#1 contains on average of $0.86 \mathrm{~g} / \mathrm{t}$ Au with a range between 0.38 and $1.65 \mathrm{~g} / \mathrm{t}[14]$.

\subsubsection{Intrusion 2 and $2 \mathrm{~A}$ (INT\#2 and INT\#2A)}

INT\#2 occurs in the center of the pit, cutting the core of INT\#1 (Figure 3). The samples from INT\#2 are fine to medium grain-sized, comprising plagioclase phenocrysts (20-30\% rock volume) up to 2 $\mathrm{mm}$ in length, in a dominantly K-feldspar groundmass (Figures $4 \mathrm{~b}$ and $5 \mathrm{~b}$ ). No quartz phenocrysts were observed. The INT\#2 zone rocks have a monzonite composition and are weakly to moderately magnetic. The INT\#2A intrusion occurs in the southeast corner of the open pit, where it cuts the margin 
of INT\#1 (Figure 3). INT\#2A is a fine to medium-grained porphyritic rock, with an intense pervasive clay-quartz alteration that appears to have selectively overprinted it (Figure 4c). INT\#2A contains phenocrysts of plagioclase ( $20 \%)$, and possibly rare quartz phenocrysts (Figure $5 \mathrm{c})$. Because of the similarity in texture between INT\#2A and INT\#2, both have been considered to be the same intrusion. The INT\#2 contains an average of $0.70 \mathrm{~g} / \mathrm{t}$ Au with a range between 0.40 and $0.96 \mathrm{~g} / \mathrm{t} \mathrm{Au}$, whereas the INT\#2A has a lower average of $0.55 \mathrm{~g} / \mathrm{t} \mathrm{Au}$ with a range between 0.37 and $0.83 \mathrm{~g} / \mathrm{t} \mathrm{Au} \mathrm{[14].}$

\subsubsection{Intrusion 3 (INT\#3)}

INT\#3 is the youngest intrusive body at the Kışladağ mine (Figure 3). It is located in the center of the INT\#1 and its dyke-like structure is elongated in an E-W direction. INT\#3 is a fine-grained porphyritic rock (Figures $4 \mathrm{~d}$ and $5 \mathrm{~d}$ ), containing unaltered plagioclase phenocrysts (20-30\%), rare quartz, and biotite phenocrysts (both $<5 \%$ ), and amphibole phenocrysts (5-10\%). The amphibole phenocrysts have been preferentially altered to chlorite, but their original prismatic shape is preserved $[14,17]$. INT\#3 contains very fine-grained disseminated primary magnetite in the groundmass, and is therefore magnetic. The bulk composition of this intrusion lies in the syenite to monzonite fields. The contacts of INT\#3 with other rocks are generally well preserved, and the decrease in gold grade is abrupt across the boundary with the other intrusions. The Au grades range from $<5$ to $200 \mathrm{ppb}$ [14].

\subsubsection{Latite Porphyry and Volcanoclastic Rocks}

The undifferentiated latite porphyry rocks cover a large area of the deposit, especially west of the mineralized intrusions (Figure 3). These rocks contain large feldspar phenocrysts in a fine-grained matrix of orthoclase and augite. The volcanoclastic rocks cover the mineralized intrusions and outcrop in the east part of the study area (Figure 3). They exhibit different textures such as fine-grained fragmental ash fall tuffs with pumice fragments (Figure 5e) to porphyritic flows with flow banding and brecciation. In some drill holes, fine-grained plagioclase-hornblende porphyries with interlayered ash fall tuffs were intersected. Due to the weak propylitic alteration, it is unclear whether these porphyries are intrusive bodies or flows. The contact between the volcanoclastics and INT\#1 is difficult to define because of the intensity of alteration, but is steeply inclined and often marked by a tourmaline-rich hydrothermal breccia (Figures 3 and $5 f$ ).
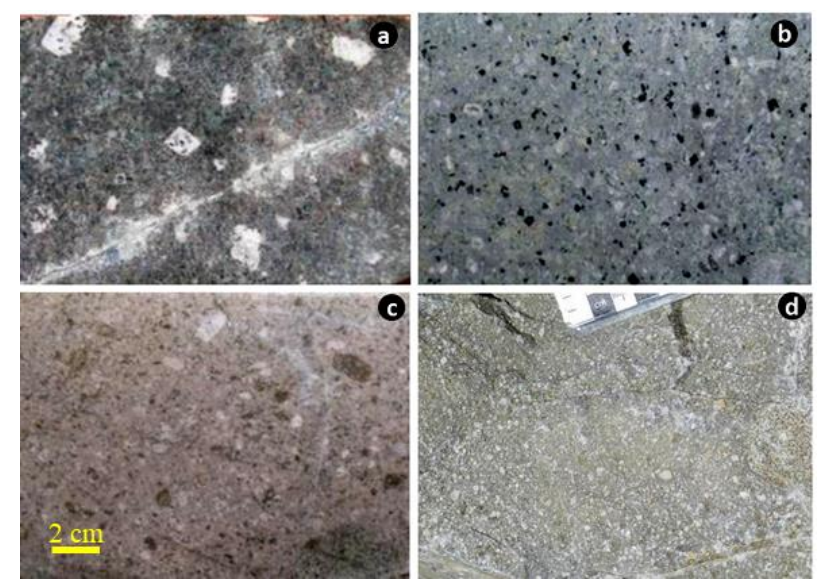

Figure 4. Macroscopic view of different intrusive rocks. (a) Intrusive 1: coarse-grained $(\sim 1 \mathrm{~cm})$ euhedral K-feldspars within the feldspar-rich groundmass. (b) Intrusive 2: medium to fine-grained (1-2 mm) subhedral plagioclase, biotite, hornblende phenocrysts within the K-feldspar dominant groundmass associated with biotite and tourmaline. (c) Intrusive 2A: intensely altered (kaolinization, sericitization) feldspar phenocrysts within the hydrothermal biotite-bearing clay-rich (phyllosilicate) altered groundmass. (d) Intrusive 3: fine-grained $(<1 \mathrm{~mm})$ unaltered feldspar and partly-chloritized amphibole phenocrysts within the feldspar and quartz groundmass (note that the width of the photos are $16 \mathrm{~cm}$ ). 

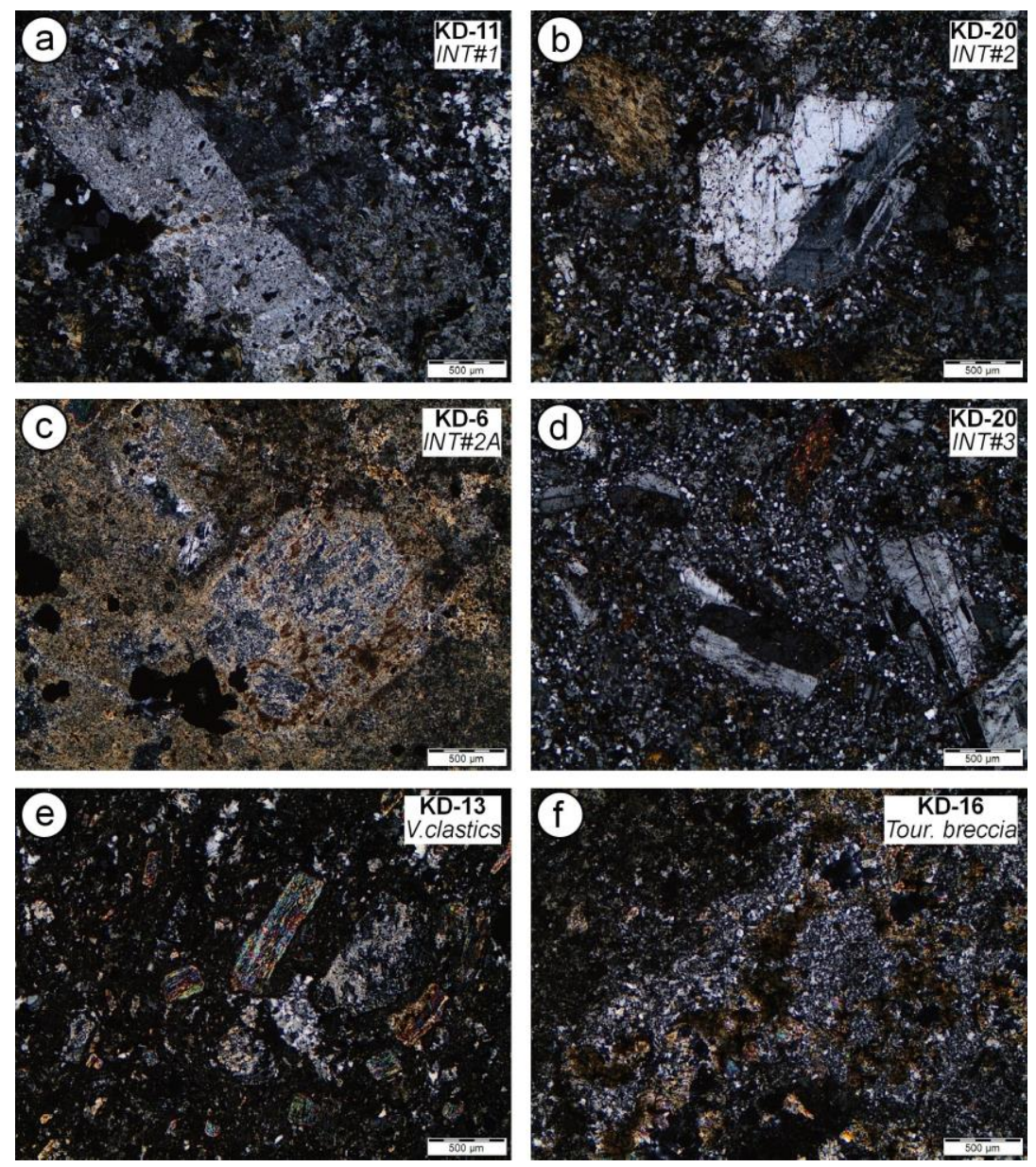

Figure 5. Optical microscopic photomicrographs of representative samples from different intrusions and volcanoclastic rocks. (a) Coarse-grained (megacryst) K-feldspar phenocryst within a silicified and hydrothermal biotite-bearing groundmass. (b) Poly-synthetic zoned plagioclase and biotite phenocrysts in a silica-rich groundmass. (c) Intensively sericitized and kaolinitized feldspar phenocrysts and groundmass with opaque minerals. (d) Euhedral poly-synthetic twinned plagioclase and partly-chloritized amphibole phenocrysts within the silicified groundmass. (e) Vitrophyric porphyritic pyroclastic rock containing silicified pumice and sericitized biotites within the devitrified volcanic groundmass. (f) Radial tourmaline occurrences and fine-grained quartz associations in the sample from the tourmaline breccia zone.

\subsection{Mineralization and Alteration}

Although the three intrusions are mineralized, the main gold mineralization in Kışladağ is related to the two earliest stages of sub-volcanic intrusions, INT\#1, INT\#2, and INT\#2A (Figure 6). Porphyry-style stockwork veins (Figure 6a,b) in mineralized intrusions include gold grains associated with pyrites that are less than $10 \mu \mathrm{m}$ in diameter [14]. These gold-hosted stockworks are represented by (i) banded quartz-pyrite-tourmaline veins (Figure 6a) in INT\#1, and (ii) tourmaline-quartz veins in INT\#2 (Figure $6 b,[14]$ ). Stockwork veins are cut by sooty pyrite \pm marcasite-tourmaline veins (Figure 6c) [14,17].

Generally, porphyry-type mineralization systems have the classic potassic, phyllic, argillic, and propylitic alteration zones (e.g., [18,19]), but in the Kışladağ deposit, only the potassic (Figure 7a), tourmaline-white mica, advanced argillic, and argillic alteration (Figure $7 \mathrm{~b}$ ) were developed [14].

The potassic alteration occurs in INT\#1, the core of the system, and it is characterized by the presence of fine-grained, red-brown secondary biotite and K-feldspar altered from a pale pink buff 
to nearly white color [14]. Euhedral (monoclinic-prismatic) adularia crystals (5 to $15 \mu \mathrm{m}$ in size) are observed in some samples from INT\#2 [20].

Tourmaline-white mica alteration occurs in and surrounds the potassic zone. The tourmaline occurs as envelopes around the quartz \pm pyrite veinlets (Figure $7 \mathrm{c}$ ) and as matrix-supported hydrothermal breccias of the wall rocks (Figure 7d).

Advanced argillic alteration is represented by quartz-alunite \pm dickite \pm pyrophyllite \pm pyrite mineral assemblages [14], which overprint potassic and tourmaline-white mica zones indicating a telescoping of the alteration zones. However, the X-ray diffraction studies of [20] did not find any evidence of pyrophyllite and dickite in the samples studied here.

Argillic alteration occurs throughout the deposit and surrounding volcanic rocks. It is dominated by the development of kaolinite and smectite [14]. Tubular halloysite crystals were also observed in the volcanoclastic units [20]. The argillic alteration overprints the all other alteration assemblages.

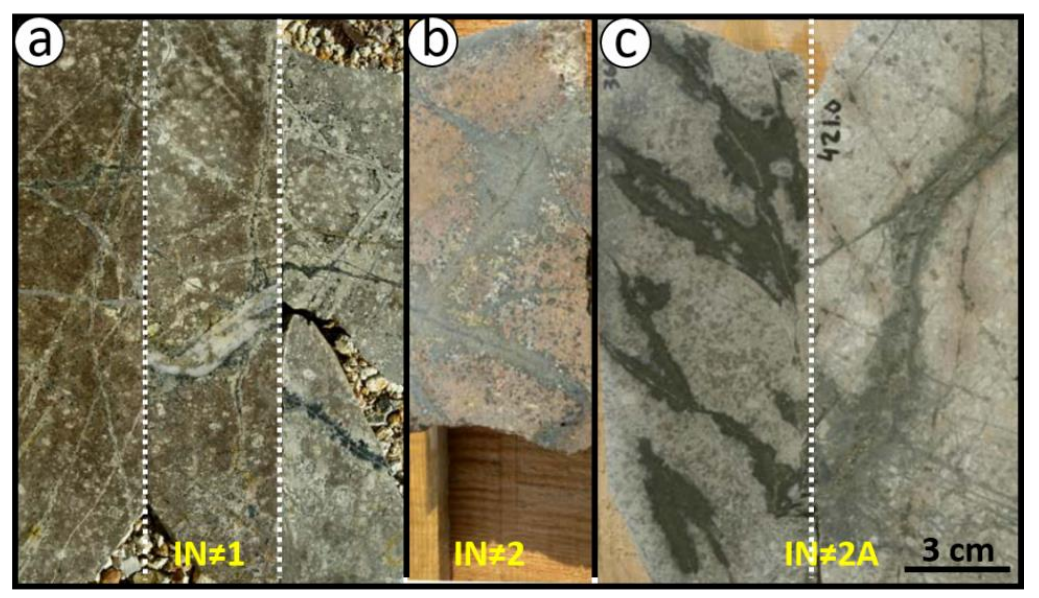

Figure 6. (a) Typical examples of mineralized stockwork veins with $1.12-0.607 \mathrm{~g} / \mathrm{t}$ Au content in Intrusion (INT\#1). (b) Tourmaline-quartz vein contains $0.27 \mathrm{~g} / \mathrm{t}$ Au overprinting the K-feldspar alteration in Intrusion 2 (INT\#2). (c) Example of the "sooty" pyrite veins with pyrite, marcasite, and tourmaline envelopes in Intrusion 2A (INT\#2A) [17].

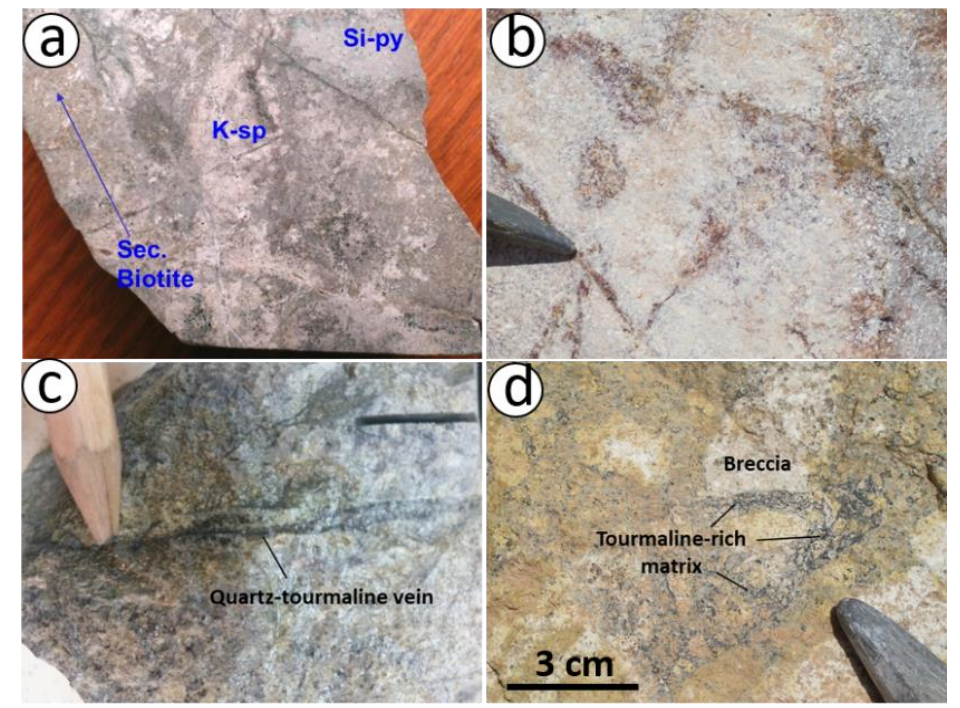

Figure 7. (a) Potassic alteration developed in INT\#1. Early secondary biotite alteration is replaced by silica-pyrite ( $\mathrm{Si}-\mathrm{py})$ flooding that is cut by later $\mathrm{K}$-feldspar (K-sp) veining [17]. (b) Advanced argillic alteration in INT\#2A. (c) Quartz-tourmaline vein cuts the potassic alteration in INT\#1 and (d) tourmaline-rich matrix-supported hydrothermal wall rock breccias. 


\section{Materials and Methods}

Samples from the Kışladağ porphyry Au deposit were collected from INT\#1, INT\#2, INT\#2A, and INT\#3 for SEM-CL and fluid inclusion studies. Approximately $100 \mu \mathrm{m}$ thick double-polished thin sections of quartz were prepared for fluid inclusion and SEM-CL studies carried out at the LEMAS laboratory of Leeds University, UK. The polished wafers were carbon-coated for SEM-CL observation using an SEM-EDX Oxford Instruments equipped with a CL detector (University of Leeds, Leeds, UK). The SEM-CL images were obtained at an acceleration voltage from 15 to $20 \mathrm{kV}$, with a beam current density of $15-20 \mathrm{nA} / \mathrm{mm}$.

Microthermometric measurements of fluid inclusions were carried out on 80-120 $\mu \mathrm{m}$ thick doubly polished quartz wafers according to standard techniques [21,22] at the fluid inclusion laboratory in Istanbul University-Cerrahpaşa, using a Linkam THMS G-600 heating-freezing stage. The stage was calibrated with pure $\mathrm{H}_{2} \mathrm{O}, \mathrm{CO}_{2}$, and $\mathrm{H}_{2} \mathrm{O}-\mathrm{NaCl}$ fluid inclusion standards, and potassium dichromate. The accuracy was determined to be $\pm 5^{\circ} \mathrm{C}$ at high temperatures and $\pm 0.2{ }^{\circ} \mathrm{C}$ at temperatures below zero. During microthermometry studies, the values of homogenization temperature $\left(\mathrm{T}_{h}\right)$, eutectic temperature ( $\mathrm{Te}$ ), last ice melting temperature ( $\mathrm{Tm}$-ice), and dissolution temperature of salt crystals present in the inclusion $(\mathrm{Tm}-\mathrm{NaCl}, \mathrm{Tm}-\mathrm{KCl})$ were measured.

\section{Results}

\subsection{Scanning Electron Microscope-Catholuminescence (SEM-CL) Imaging}

The SEM-CL study was performed on polished quartz wafers (Figure 8a) from the three different intrusions (three wafers from INT\#1, three wafers from INT\#2, and four wafers from INT\#3). In the studied samples, two veins (V1 and V2 veins) are clearly identified from their crosscutting relationship in INT\#1 and INT\#2 (Figure 8). The stockwork veins (V1 vein) that include gold [14] in both INT\#1 and INT\#2 (Figure 8a) are cut by V2 veins in INT\#2 and INT\#3 (Figure 8b).

Detailed CL images (Figure 9a-d) revealed multiple generations (Figure 9d) of quartz formation both in V1 and V2 veins. In V1 veins, these are: (i) CL-light gray, early formed mosaic-equigranular quartz (Q1; Figure 10a); (ii) CL-gray or CL-bright quartz (Q2) that dissolved and was subsequently overgrown on Q1, or formed dissolution cavities in Q1 quartz (Figure 10b); (iii) concentric growth zoned quartz (Q3) alternating CL-dark and CL-gray bands are particularly developed in V2 veins in INT\#2 and INT\#3 (Figure 10b,c); and (iv) CL-dark or CL-gray micro-fracture filling late-stage quartz (Q4) developed both in V1 and V2 in all intrusions (Figure 10a,c). In V2 vein, CL-gray-to dark gray quartz (Q2) which developed by dissolution around the zoned quartz (Q3), is accompanied by pyrite \pm sphalerite (Figure 8b). This suggests that the dissolution of quartz (Q2) and sulfides developed from the same fluids after V1 quartz deposition. Similar CL-textures have been reported in other porphyry deposits such as No.2 [23], Butte Montana [24], and Bingham Canyon [25].

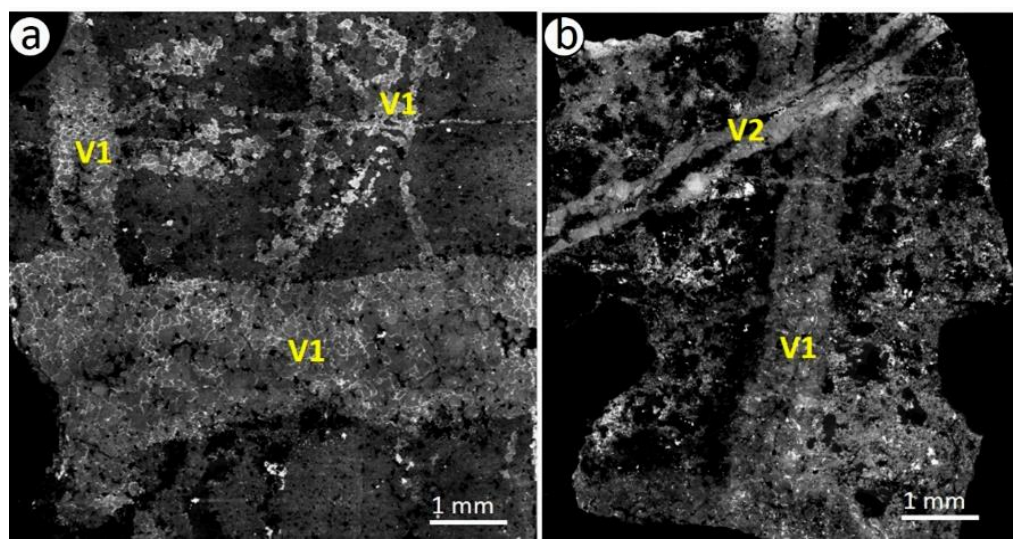

Figure 8. SEM-CL images of quartz veins (V1 and V2) in INT\#1 (a) and in INT\#2 (b). 

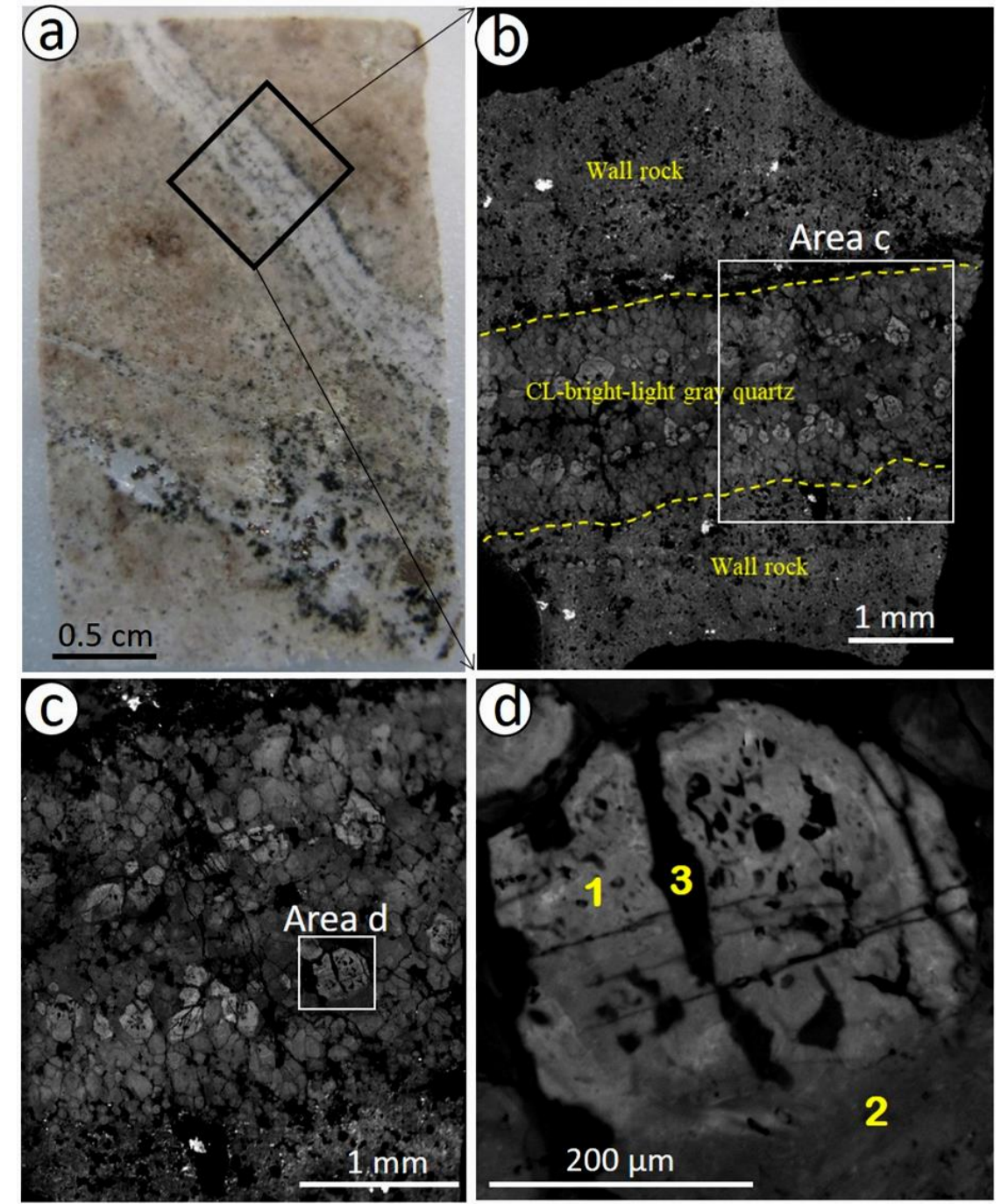

Figure 9. (a) Doubly polished thin section of INT\#1 (sample KD-3a). (b) SEM-CL image of early quartz vein cutting potassic alteration. (c) SEM-CL image clearly shows multiple generations of quartz with CL-bright and CL-gray quartz. (d) At least three generations of quartz formation (1 to 3) are identified as CL- bright, CL-gray (dissolution qtz), and CL-dark, which is the last generation.

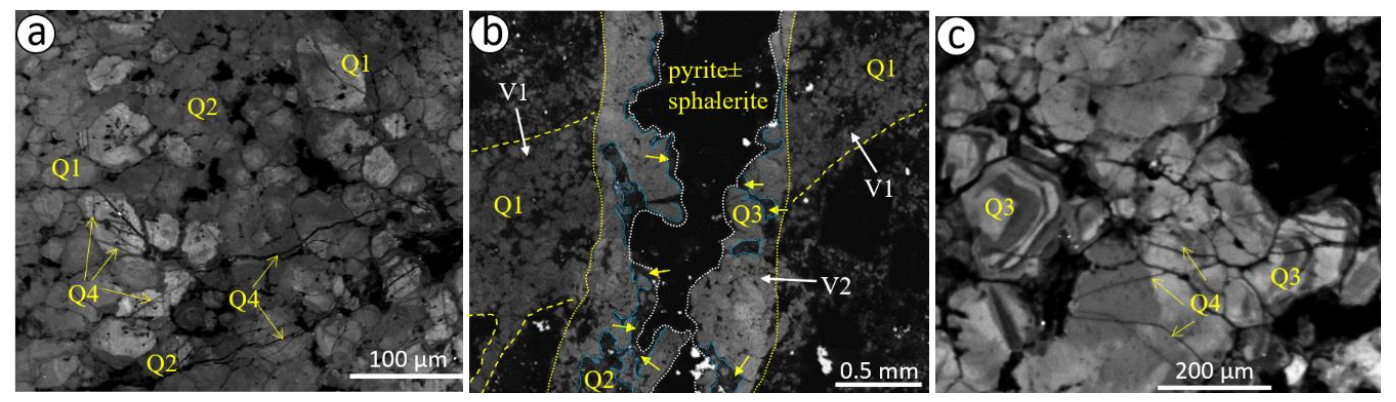

Figure 10. Multiple generations of quartz formation identified by SEM-CL imaging in (a) INT\#1, (b) INT\#2, and (c) INT\#3. (Q1) CL-bright, light grey early generation, (Q2 and yellow arrows) CL-dark grey, dissolution quartz, (Q3) CL-dark grey and light grey bands, concentric zoning quartz, and (Q4) CL-grey to dark grey, micro-fracture filling, late-stage quartz. 


\subsection{Fluid Inclusion Studies}

Microthermometric studies were carried out on quartz veins in INT\#1, INT\#2, and INT\#3. Fluid inclusions have been described as primary and secondary according to the criteria of [21,26]. The size of the studied fluid inclusions varies between 10 and $40 \mu \mathrm{m}$, rarely exceeding $60 \mu \mathrm{m}$. Four different types of fluid inclusion assemblages (FIAs; Figure 11) were identified in the studied samples on the basis of phase assemblages observed at room temperature. These are: (i) aqueous liquid-vapor (LV-type) inclusions in which the liquid phase is dominant (Figure 12a); (ii) aqueous vapor-liquid (VL-type) inclusions (Figure 12b,c) in which the vapor phase is greater than 70\%; (iii) aqueous liquid-carbonic fluid-vapor (LCV-type) inclusions (Figure 12d); and (iv) aqueous liquid-vapor-solid (LVS-type) inclusions (Figure 12e,f), which contain solid daughter phase(s). While the LV-and LVS-type inclusions homogenized to liquid, the VL-type homogenized to a vapor phase, or decrepitated prior to homogenization. The daughter minerals (halite and sylvite) dissolved before vapor disappearance in LVS-type inclusions.
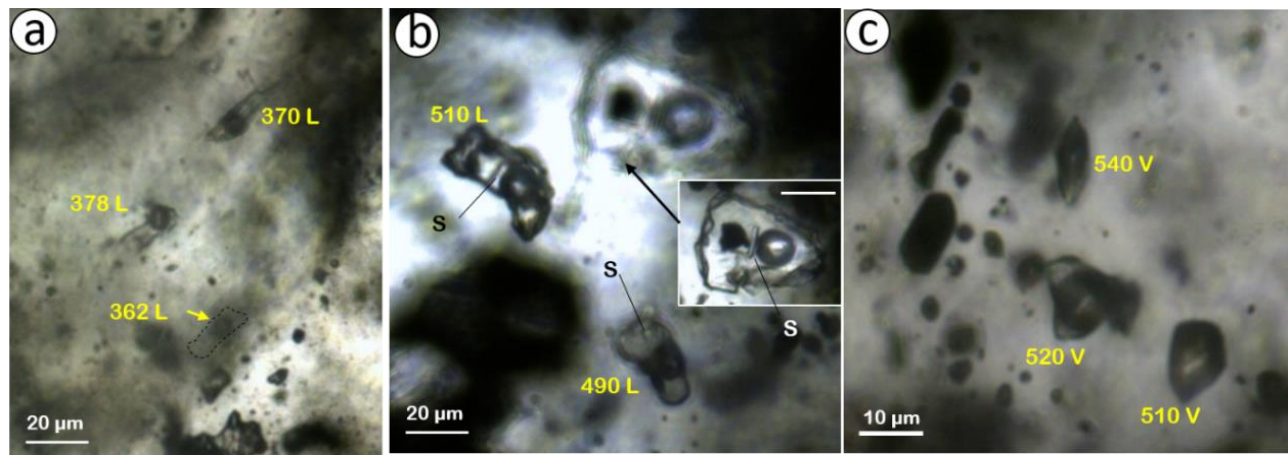

Figure 11. Fluid inclusion assemblages (FIAs) identified at room temperature as (a) LV-type in INT\#2, (b) LVS-type in INT\#1, and (c) VL-type in INT\#2. (S: solid phase; L: homogenization into liquid phase; V: homogenization into vapor phase). Numbers and letters are the temperature and type of homogenization, Liquid or Vapor.

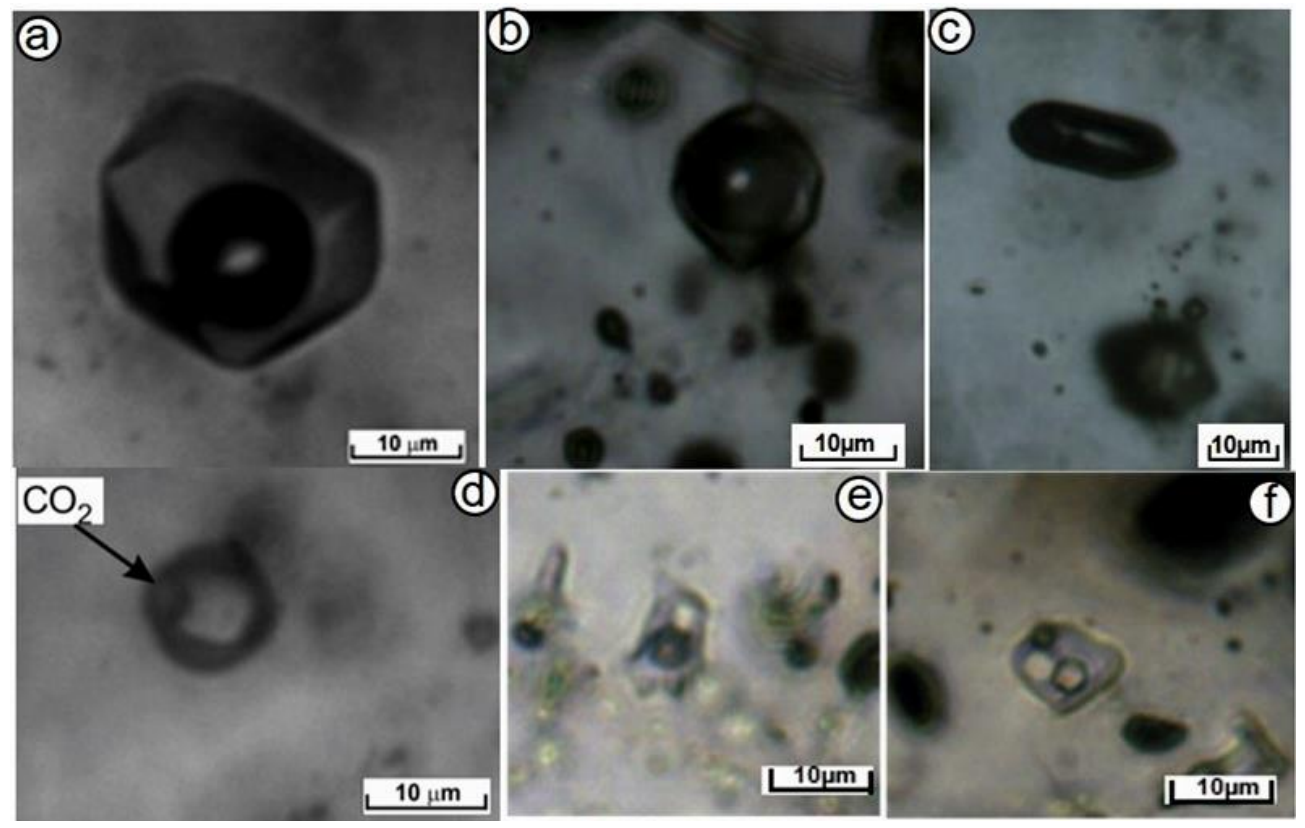

Figure 12. Fluid inclusion types distinguished according to the phases present at room temperature. (a) LV-type, (b,c) VL-type, (d) LCV-type, and (e,f) LVS-type inclusions. 
Microthermometric measurements were carried out on fluid inclusions that were trapped during the formation of different generations of quartz (Q1, Q2, etc., see Figure 10) identified by SEM-CL imaging. The microthermometric data are summarized in Table 1.

Table 1. Summary of microthermometric results from the different veins and quartz types of Kışladağ Au deposit (Te: eutectic temperature; Tm: melting temperature; Clth: clathrate; L: liquid; V: vapor; n: number, n.d. = not determined).

\begin{tabular}{|c|c|c|c|c|c|c|c|c|c|c|c|c|}
\hline Intrusion & $\begin{array}{l}\text { Vein } \\
\text { Type }\end{array}$ & $\begin{array}{c}\text { Quartz } \\
\text { Generation }\end{array}$ & $\begin{array}{c}\text { Fluid } \\
\text { Inclusion } \\
\text { Type, (n) }\end{array}$ & $\begin{array}{l}\mathrm{Te} \\
{ }^{\circ} \mathrm{C}\end{array}$ & $\underset{{ }^{\circ} \mathrm{C}}{\mathrm{Tm}-\mathrm{CO}_{2}}$ & Tm-Ice ${ }^{\circ} \mathrm{C}$ & $\begin{array}{c}\text { Tm-Clth } \\
{ }^{\circ} \mathrm{C}\end{array}$ & $\begin{array}{c}\mathrm{T}_{\mathrm{h}}-\mathrm{CO}_{2} \\
{ }^{\circ} \mathrm{C} C\end{array}$ & $\begin{array}{c}\text { Tm-Halite } \\
{ }^{\circ} \mathrm{C}\end{array}$ & $\begin{array}{c}\text { Salinity } \\
\mathrm{NaCl} \\
\text { wt } \% \text { equiv. }\end{array}$ & $\begin{array}{c}\mathrm{T}_{\mathrm{h}} \text { Values } \\
{ }^{\circ} \mathrm{C}\end{array}$ & $\begin{array}{c}T_{h} \\
\text { Mode }\end{array}$ \\
\hline \multirow{6}{*}{ INT\#1 } & V1 & Q1 & LVS, (5) & -70 to -17 & - & - & - & - & 250 to 412 & 34 to 49 & 435 to 510 & $\mathrm{~L}$ \\
\hline & V1 & $\mathrm{Q} 1$ & $\operatorname{LV}(7)$ & -71 to -30 & - & -7 to -1 & - & - & - & 2 to 11 & 293 to 378 & $\mathrm{~L}$ \\
\hline & V1 & $\mathrm{Q} 2$ & LV (3) & n.d. & - & -8 to -1 & - & - & - & 3 to 11 & 336 to 346 & $\mathrm{~L}$ \\
\hline & V1 & $\mathrm{Q} 2$ & $\operatorname{LCV}(4)$ & -70 to -67 & -58.5 to -54 & - & - & 21 & - & - & 350 & $\mathrm{~L}$ \\
\hline & V1 & Q2-Q4 & LVS & -26 & - & - & - & - & 112 to 261 & 28 to 35 & 250 to 351 & $\mathrm{~L}$ \\
\hline & V1 & Q2-Q4 & LV (14) & -45 to -26 & - & -8.5 to -2 & 2.6 & - & - & 3 to 12.5 & 257 to 333 & $\mathrm{~L}$ \\
\hline \multirow[t]{3}{*}{ INT\#2 } & V1 & Q2 & LV (10) & -52 to -28 & - & -17 to -5 & - & - & - & 20 to 7.5 & 303 to 380 & $\mathrm{~L}$ \\
\hline & V1 & $\mathrm{Q} 2$ & VL (2) & -38 to -36 & - & -11 to -4 & - & - & - & 15 to 7 & 377 to 381 & $\mathrm{~V}$ \\
\hline & V2 & Q3 & LV (3) & -42 to -37 & - & -7 to -5 & - & - & - & 10 to 7 & 340 to 300 & $\mathrm{~L}$ \\
\hline \multirow{4}{*}{ INT\#3 } & V1 & Q1 & LVS (2) & -93 to -40 & - & - & - & - & 228 to 219 & 33 & 412 to 469 & $\mathrm{~L}$ \\
\hline & V1 & Q1 & LV (8) & -101 to -40 & - & -10.4 & 7.2 & - & & 15 to 5 & 310 to 520 & $\mathrm{~L}$ \\
\hline & V1 & Q1 & VL (2) & -90.3 & - & - & 7.8 & - & - & 4.3 & 600 & $\mathrm{~V}$ \\
\hline & V2 & Q3 & LV (5) & -26.4 & - & -4.8 to -3.3 & - & - & - & 7.6 to 5.4 & 373 to 310 & $\mathrm{~L}$ \\
\hline
\end{tabular}

\subsubsection{Intrusion\#1 (INT\#1)}

Fluid inclusion data were obtained from the V1 veins in Q1, Q2, and Q4 from INT\#1 (Table 1). LVS-, LV-, and VL-type inclusions were identified in Q1, while Q2 also includes LCV-type inclusions. LVS-type inclusions contain a halite daughter mineral that dissolved between 250 and $412{ }^{\circ} \mathrm{C}$ representing a salinity of 34 to $49 \mathrm{wt} \% \mathrm{NaCl}$ equivalent. These inclusions homogenized between 435 and $510{ }^{\circ} \mathrm{C}$ into liquid by the disappearance of the vapor bubble. Some of the LVS inclusions in Q1 contain an opaque solid phase (Figure 11b) which optically looks to be hematite due to its slightly reddish color, and are common in the mineralizing fluids of porphyry deposits. The last ice melting (Tm-ice) temperature of the VL-type inclusions in Q1 was between -5.3 and $-1.8{ }^{\circ} \mathrm{C}$ representing $1 \%$ to $7 \% \mathrm{NaCl}$ equivalent salinity. The VL-type inclusions homogenized to the vapor phase between 424 and $520{ }^{\circ} \mathrm{C}$. The high salinity LVS and low salinity LCV-type inclusions with similar $T_{h}$ values indicate that these fluid inclusions represent separated phases of the primary magmatic fluid. The range in $T_{h}$ values and that some VL inclusions decrepitate prior to homogenization may indicate that some liquid was trapped when the vapor separated. The later trapped LV-type inclusions have eutectic and Tm-ice values between -71 and $-30{ }^{\circ} \mathrm{C}$ and -7 and $-1{ }^{\circ} \mathrm{C}$, respectively (Table 1 ). They have salinity and $\mathrm{T}_{\mathrm{h}}$ between 2 and 11 wt \% $\mathrm{NaCl}$ equiv., and between 293 and $378{ }^{\circ} \mathrm{C}$, respectively.

The microthermometric data of the LV-type inclusions in Q2 of the V1 vein are similar to the LV-type inclusions of Q1 (Table 1). The Tm-ice values range from -8 to $-1{ }^{\circ} \mathrm{C}$ corresponding to salinities between 3 and 11 wt \% NaCl equivalent. These inclusions homogenized between 336 and $346{ }^{\circ} \mathrm{C}$. The presence of $\mathrm{CO}_{2}$ was detected in inclusions from Q2 in the V1 vein. The melting temperature of solid $\mathrm{CO}_{2}$ was from -58.5 to $-54{ }^{\circ} \mathrm{C}$ indicating $\mathrm{CO}_{2}$ is the dominant gas, with at best only very minor other gaseous components being present. However, the clathrate and last ice melting temperature could not be determined due to the size of the inclusions. The LCV-type inclusions have $T_{h}$ values of $350{ }^{\circ} \mathrm{C}$.

Two LVS and fourteen LV-type inclusions could not be identified as belonging to either Q2 or Q4 (Table 1). Two LVS-type inclusions include halite daughter minerals that dissolved at 112 and $261{ }^{\circ} \mathrm{C}$ representing $28 \%$ and $35 \% \mathrm{NaCl}$ equiv. salinity. The $\mathrm{T}_{\mathrm{h}}$ values of these inclusions were between 250 and $351{ }^{\circ} \mathrm{C}$. The LV-type inclusions in this group (Q2 or Q4) have Te and Tm-ice values ranging from -45 to $-26{ }^{\circ} \mathrm{C}$, and from -8.5 to $-2{ }^{\circ} \mathrm{C}$, respectively. In a few inclusions, there was no $\mathrm{CO}_{2}$ phase $^{\circ}$ detected at room temperature; however, the presence of clathrate was detected when heated to $2.6^{\circ} \mathrm{C}$ 
(Table 1). The salinity and $\mathrm{T}_{\mathrm{h}}$ values of these inclusions were between 3 and $12.5 \mathrm{wt} \% \mathrm{NaCl}$ equiv., and between 257 and $333^{\circ} \mathrm{C}$, respectively.

\subsubsection{Intrusion\#2 (INT\#2)}

The LV- and VL-type fluid inclusions were detected in Q1, Q2, and Q3 quartz of V1 and V2 veins in INT\#2 (Table 1). LV- and VL-type inclusions have similar Te values ranging from -68 to $-43^{\circ} \mathrm{C}$, and -68 to $-38^{\circ} \mathrm{C}$, respectively. Tm-ice values were between -14 and $-11^{\circ} \mathrm{C}$ in LV-type inclusions corresponding to between 16 and 18 wt \% NaCl equiv. salinity, while Tm-ice was not detected in VL-type inclusions. Although the $T_{h}$ values of LV-type (from 371 to $443{ }^{\circ} \mathrm{C}$ ) are lower than the $T_{h}$ values of VL-type (from 480 to $594^{\circ} \mathrm{C}$ ) inclusions, we suggest the two inclusion types represent fluid separation pairs. The higher $\mathrm{T}_{\mathrm{h}}$ values of some VL inclusions may be artificially high due to trapping of small amounts of liquid with the vapor.

The Q2 of V1 veins contains LV- and VL-type inclusions (Table 1). Both have similar ranges of Te (from -52 to $-28{ }^{\circ} \mathrm{C}$ for $\mathrm{LV}$ and -38 to $-36{ }^{\circ} \mathrm{C}$ for VL-type), salinity (from $7 \%$ to $20 \% \mathrm{NaCl}$ equiv. for $\mathrm{LV}$ and $7 \%$ to $15 \% \mathrm{NaCl}$ equiv. for VL-type), and $\mathrm{T}_{\mathrm{h}}$ (from 303 to $380^{\circ} \mathrm{C}$ for $\mathrm{LV}$ and 377 to $381{ }^{\circ} \mathrm{C}$ for VL-type).

The V2 vein in INT\#2 includes sulfides (pyrite \pm sphalerite) that cut the V1 vein. This vein includes LV-type inclusions in Q3. The Te and Tm-ice values of these LV-type inclusions range from -42 to $-37^{\circ} \mathrm{C}$, and from -7 to $-5^{\circ} \mathrm{C}$, respectively (Table 1 ). The salinity and $\mathrm{T}_{\mathrm{h}}$ value of these inclusions was between 7 and 10 wt \% $\mathrm{NaCl}$ equiv., and between 300 and $340{ }^{\circ} \mathrm{C}$, respectively.

\subsubsection{Intrusion\#3 (INT\#3)}

Microthermometric measurements were obtained from the V1 and V2 veins of INT\#3 which contain uneconomic gold mineralization. While LV-, LVS-, and VL-type inclusions are identified in Q1, the Q2 and Q3 contain only LV-type inclusions (Table 1). The Te values of the two LVS-type inclusions in Q1 are -93 and $-40{ }^{\circ} \mathrm{C}$. The solid phase was identified as halite due to its rounded cube edges. The dissolution temperature was measured at 228 and $219^{\circ} \mathrm{C}$, which corresponds to $33 \% \mathrm{NaCl}$ salinity. These types of inclusions were homogenized by disappearance of the vapor bubble between 412 and $469{ }^{\circ} \mathrm{C}$ (Figure 13).
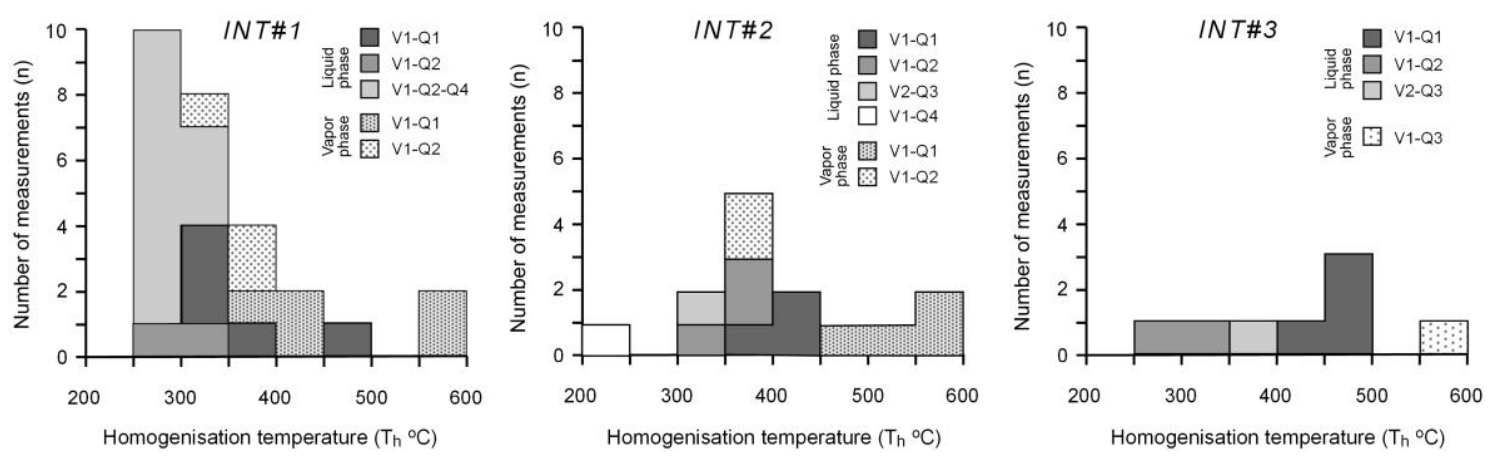

Figure 13. The distribution of the homogenization temperatures $\left(\mathrm{T}_{\mathrm{h}},{ }^{\circ} \mathrm{C}\right)$ of the fluid inclusions in different generations of quartz from the different intrusions.

The VL-type inclusions in Q1 have similar Te values to the LVS-type at $-93{ }^{\circ} \mathrm{C}$, and have a very low salinity of $4.3 \% \mathrm{NaCl}$ equiv. The $\mathrm{T}_{\mathrm{h}}$ values of this type of inclusion were measured at higher than $600{ }^{\circ} \mathrm{C}$. In this instance, the $\mathrm{T}_{\mathrm{h}}$ values of VL-type inclusions are much higher than LVS-type inclusions and therefore it is less likely the two fluid inclusion types are linked. However, more data would help to confirm the very high $\mathrm{T}_{\mathrm{h}}$ of the VL inclusions.

The LV-type inclusions in Q1 have Te values between -101 and $-40{ }^{\circ} \mathrm{C}$ and a Tm-ice value at $-10.4{ }^{\circ} \mathrm{C}$. The formation of clathrate, and its dissolution temperature of $7.2^{\circ} \mathrm{C}$ in LV-type inclusions, 
indicates the existence of $\mathrm{CO}_{2}$ in the fluids. The $\mathrm{T}_{\mathrm{h}}$ and salinity values of $\mathrm{LV}$-type inclusions range from 310 to $520^{\circ} \mathrm{C}$, and $5 \%$ to $15 \% \mathrm{NaCl}$ equiv., respectively.

The V2 vein of INT\#3 contains Q3, which exhibits a growth zone texture. The Q3 includes LV-type inclusions that have Te and Tm-ice values of $-26.4{ }^{\circ} \mathrm{C}$, and between -4.8 and $-3.3{ }^{\circ} \mathrm{C}$, respectively (Table 1). The salinity and $\mathrm{T}_{\mathrm{h}}$ value of these inclusions range from 5.4 to $7.6 \mathrm{wt} \% \mathrm{NaCl}$ equiv., and 310 to $373{ }^{\circ} \mathrm{C}$, respectively. The lower salinity and $\mathrm{T}_{\mathrm{h}}$ value of fluids in Q3 compared to the fluids in Q1 is quite distinct and may indicate that the deposition of Q3 was linked with mixing of a meteoric fluid with a magmatic fluid.

\section{Discussion and Conclusions}

Fluid Inclusion data provide valuable information in understanding the physico-chemical features of fluids in hydrothermal systems, and are very common in stockwork quartz veins of porphyry-type mineralization. However, it is well established that multiple generations of quartz occur due to episodic fluid flow within individual hydrothermal quartz veins in porphyry, epithermal deposits systems (e.g., [24,27-30]). Therefore, it is important to be able to identify the quartz generations and relate the characteristics of the fluids they contain with mineralization. Application of SEM-CL imaging improves the ability to constrain the timing of fluid inclusions and the quartz generations in veins compared with more traditional fluid inclusion petrography studies [24,29,31].

The presence of gold mineralization in three different intrusions (INT\#1 to \#3) in the Kişladağ gold deposit can be related to different phases of quartz veining. Using SEM-CL imaging clearly shows the presence of different quartz generations, $Q 1$ to $Q 4$, in different vein generations in the different intrusions. Fluid inclusion studies were then related to the different vein (V1 and V2) and quartz generations (Q1 to Q4) that occur. Even though there is no quantitative microanalysis of fluids in Q1, due to the presence of opaque minerals in LVS inclusions, the CL-bright, light gray luminescence quartz (Q1) in V1 vein should be the earliest formed gold-hosted quartz. Fluid inclusion data show that the Q1 of V1 vein in INT\#1 is related with immiscible fluids shown by the co-existence of LVS, which have $\mathrm{T}_{\mathrm{h}}$ between 435 and $510{ }^{\circ} \mathrm{C}$, with $>40 \% \mathrm{NaCl}$ salinity, and VL-type inclusions with $\mathrm{T}_{\mathrm{h}}$ between 424 and $520{ }^{\circ} \mathrm{C}$, with $1 \%$ to $7 \% \mathrm{NaCl}$ equiv. salinity (Table 1; Figure 14). Coexisting liquid-rich highly saline and vapor-rich low saline inclusions in most hydrothermal deposits indicate the different phases were generated by immiscibility (e.g., [21,32]).

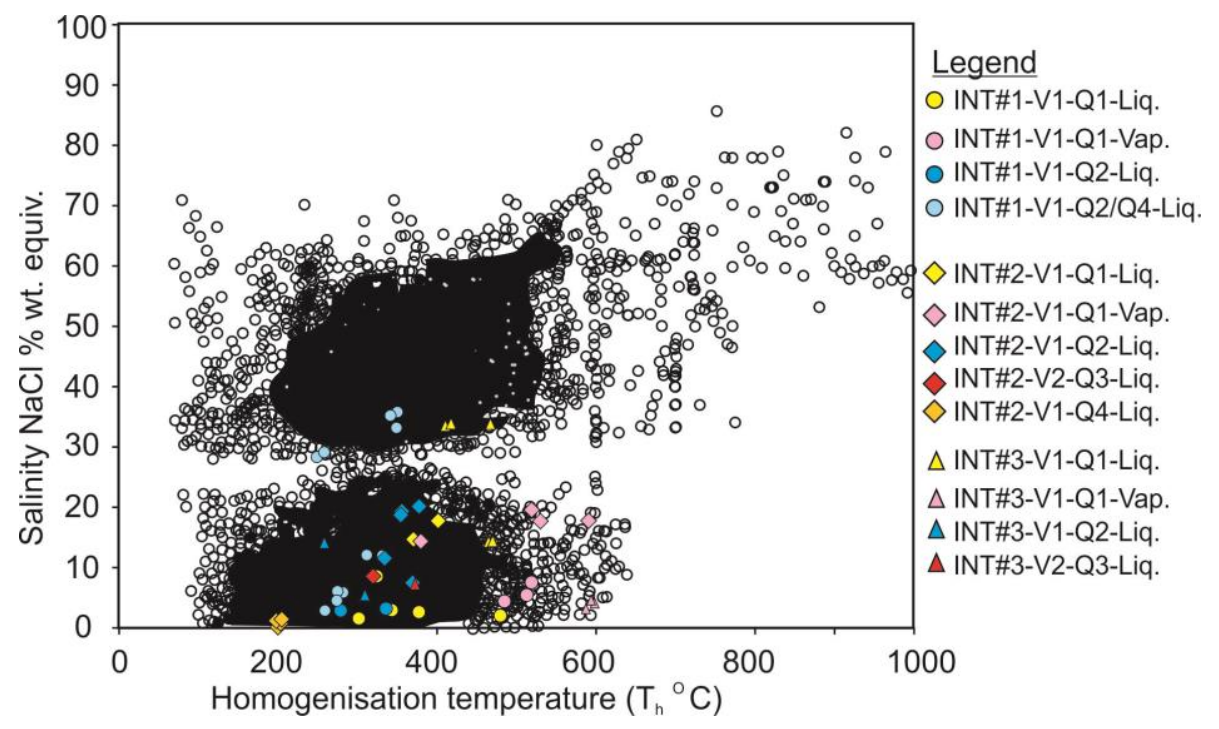

Figure 14. Homogenization temperature versus salinity of world porphyry copper deposits (from [33]) compared with Kışladağ data. 
The quartz of the V1 vein in INT\#2 also contains LV- and VL-type inclusions, indicating fluid immiscibility, which have a $\mathrm{T}_{\mathrm{h}}$ range of $371-443{ }^{\circ} \mathrm{C}$ and $480-594{ }^{\circ} \mathrm{C}$, respectively. The existence of immiscibility during the formation of gold-bearing Q1 in the V1 veins of both INT\#1 and INT\#2 indicates the $T_{h}$ values are equal to the trapping temperature. The $T_{h}$ and salinity values of the Q2 in V1 veins of both INT\#1 and INT\#2 have similar ranges $\left(\mathrm{T}_{\mathrm{h}}\right.$ between 336 and $380^{\circ} \mathrm{C}$ ) and are lower than the $\mathrm{Q} 1 \mathrm{~T}_{\mathrm{h}}$ values. The low $\mathrm{CO}_{2}$ content of the $\mathrm{Q} 1$ and $\mathrm{Q} 2$ can be used to infer a shallow depth of trapping. $\mathrm{CO}_{2}$-rich fluids in porphyry systems are generally indicative of depths of $1-5 \mathrm{~km}$ and the shallow depth $(<1 \mathrm{~km})$ has been suggested (e.g., $[14,23,34,35])$ as an important factor in the gold-rich nature of Kışladağ deposit. The late-stage fluid, represented by Q3 associated with sulfides in V2 veins both of INT\#2 and INT\#3, has lower salinities (from $5 \%$ to $10 \% \mathrm{NaCl}$ equiv.) and $\mathrm{T}_{\mathrm{h}}$ (from 300 to $373{ }^{\circ} \mathrm{C}$ ) than the earlier gold-bearing Q1 (Figure 14). Finally, LV-type inclusions in Q4, which is the micro-fracture filling and represents late-stage fluids, have lower $\mathrm{T}_{\mathrm{h}}$ (from 257 to $333^{\circ} \mathrm{C}$ ) and salinities (from $3 \%$ to $12.5 \% \mathrm{NaCl}$ equiv.) Both $\mathrm{T}_{\mathrm{h}}$ and salinity are lower than other quartz generations and may indicate dilution of magmatic fluids by meteoric water. However, the overprinting of the porphyry mineralizing stage by a late-stage epithermal system is also possible. Telescoping in porphyry-epithermal systems is known and [14] has suggested this has occurred at the Kışladağ occurrences. Therefore, we suggest that the vein and quartz associations and the temperatures and salinities we have measured are best explained as supporting the process of a late-stage epithermal overprint of the porphyry mineralization.

The general scenario is one of the repeated pulses of fluids typical for a porphyry system followed by a change to the lower temperatures of epithermal systems. However, as the pulses of fluids progress with time, the amount of gold mineralization decreased from INT\#1 to INT\#3, and this suggests that the source reservoir was being depleted in some critical metals.

Author Contributions: Investigation, N.H. and G.B., formal analysis, N.H. and V.P., writing-original draft preparation, N.H., Ö.B., and D.A.B.; resources, N.H., G.B., D.B., Ö.B., and Y.Ö. All authors have read and agreed to the published version of the manuscript.

Funding: This research received no external funding.

Acknowledgments: The authors would like to thank the TÜPRAG mining company for their permission to investigate the mining site.

Conflicts of Interest: The authors declare no conflicts of interest.

\section{References}

1. Reynolds, N.; Large, D. Tethyan zinc-lead metallogeny in Europe, North Africa, and Asia. Soc. Econ. Geol. Spec. Pub. 2010, 15, 339-365.

2. Richards, J.P. Tectonic, magmatic, and metallogenic evolution of the Tethyan orogeny: From subduction to collision. Ore Geol. Rev. 2015, 70, 323-345. [CrossRef]

3. Şengör, A.M.C.; Yılmaz, Y. Tethyan evolution of Turkey: A plate tectonic approach. Tectonophysics 1981, 75, 181-241. [CrossRef]

4. Elmas, A.; Yılmaz, Y. Development of an oblique subduction zone tectonic evolution of the Tethys Suture zone in Southeast Turkey. Int. Geol. Rev. 2003, 5, 827-840. [CrossRef]

5. Seyitoğlu, G.; Scott, B.C. Late Cenozoic crustal extension and basin formation in west Turkey. Geol. Mag. 1991, 128, 155-166. [CrossRef]

6. Bozkurt, E.; Mittwede, S.K. Introduction: Evolution of continental extensional tectonics of western Turkey. Geodin. Acta 2005, 18, 153-165. [CrossRef]

7. Yılmaz, Y. The origin of young volcanic rocks of western Turkey. In Tectonic Evolution of the Tethyan Region; Sengor, A.M.C., Ed.; Springer: Dordrecht, The Netherlands, 1989; Volume 259, pp. 159-189.

8. Savaşçın, M.Y. Magmatic activities of Cenozoic compressional and extensional tectonic regimes in western Anatolia. In Proceedings of the International Earth Sciences Congress on Aegean Regions (IESCA), Izmir, Turkey, 1-6 October 1990; pp. 420-434. 
9. Yilmaz, Y. Morphotectonic Development of Anatolia and the Surrounding Regions. In Active Global Seismology: Neotectonics and Earthquake Potential of the Eastern Mediterranean Region, 1st ed.; Geophysical Monograph 225; Çemen, İ., Yılmaz, Y., Eds.; John Wiley \& Sons, Inc.: Hoboken, NJ, USA, 2012; pp. 11-91.

10. Koçyiğit, A.; Yusufoğlu, H.; Bozkurt, E. Evidence from the Gediz graben for episodic two-stage extension in western Turkey. J. Geol. Soc. (Lond.) 1999, 156, 605-616. [CrossRef]

11. Karaoğlu, Ö.; Helvacı, C. Growth, destruction and volcanic facies architecture of three volcanic centres in the Miocene Uşak-Güre basins: A contribution to the discussion on the development of east-west and north trending basins in western Turkey. Geol. Mag. 2012, 134, 163-175.

12. Kuşcu, İ.; Tosdal, R.M.; Gençalioğlu-Kuşcu, G. Porphyry-Cu Deposits of Turkey. In Mineral Resources of Turkey Modern Approaches in Solid Earth Sciences; Pirajno, F., Ünlü, T., Dönmez, C., Şahin, M., Eds.; Springer: Cham, Switzerland, 2019; Volume 16, pp. 337-425.

13. Available online: https://www.eldoradogold.com/news-and-media/news-releases/press-release-details/ 2018/Eldorado-Gold-Releases-Updated-Reserve-and-Resource-Statement/default.aspx (accessed on 1 November 2019).

14. Baker, T.; Bickford, D.; Juras, S.; Lewis, P.; Oztas, Y.; Ross, K.; Tukac, A.; Rabayrol, F.; Miskovic, A.; Friedman, R.; et al. The Geology of the Kışladağ Porphyry Gold Deposit, Turkey. In Tectonics and Metallogeny of the Tethyan Orogenic Belt; Richards, J.P.R., Ed.; Special Publication Society of Economic Geologists, GeoScienceWorld: Virginia, VA, USA, 2016; Volume 19, pp. 57-83.

15. Karaoğlu, Ö.; Helvac1, C.; Ersoy, Y. Petrogenesis and ${ }^{40} \mathrm{Ar} /{ }^{39} \mathrm{Ar}$ geochronology of the volcanic rocks of the Uşak-Güre basin, western Türkiye. Lithos 2010, 119, 193-210. [CrossRef]

16. Seyitoğlu, G. Late Cenozoic tectono-sedimentary development of the Selendi and Uşak-Güre basins: A contribution to the discussion on the development of east-west and north trending basins in western Turkey. Geol. Mag. 1997, 134, 163-175. [CrossRef]

17. Juras, S.; Miller, R.; Skayman, P. Technical Report for the Kışladağ Gold Mine. Prep. Eldorado Gold 2010, 43-101, 150.

18. Lowell, J.D.; Guilbert, J.M. Lateral and vertical alteration-mineralization zoning in porphyry ore deposits. Econ. Geol. 1970, 65, 373-408. [CrossRef]

19. Sillitoe, R.H. The tops and bottoms of porphyry copper deposits. Econ. Geol. 1973, 68, 799-815. [CrossRef]

20. Bozkaya, Ö.; Bozkaya, G.; Hanilçi, N.; Laçin, D.; Banks, D.A.; Uysal, I.T. Mineralogical and geochemical evidence of late epithermal alteration in the Kisladag porphyry gold deposit, Usak, Western Turkey. In Life with Ore Deposits on Earth, Proceedings of the 15th Biennial SGA Conference, Glasgow, UK, 27-30 August 2019; Society for Geology Applied to Mineral Deposits, University of Glasgow: Scotland, UK, 2019; Volume 3, pp. 1031-1034.

21. Roedder, E. Fluid inclusion evidence for immiscibility in magmatic differentiation. Geochim. Cosmochim. Acta 1992, 56, 5-20. [CrossRef]

22. Shepherd, T.; Rankin, A.H.; Alderton, D.H.M. A Practical Guide to Fluid Inclusion Studies; Blackie: Glasgow, UK, 1985; p. 239.

23. Lang, X.; Wang, X.; Deng, Y.; Tang, J.; Xie, F.; Yang, Z. Hydrothermal evolution and ore precipitation of the No. 2 porphyry $\mathrm{Cu}-\mathrm{Au}$ deposit in the Xiongcun district, Tibet: Evidence from cathodoluminescence, fluid inclusions, and isotopes. Ore Geol. Rev. 2019, 114, 103141. [CrossRef]

24. Rusk, B.G.; Reed, M.H. Scanning electron microscope-cathodoluminescence of quartz reveals complex growth histories in veins from the Butte porphyry copper deposit, Montana. Geology 2002, 30, 727-730. [CrossRef]

25. Redmond, P.B.; Einaudi, M.T.; Inan, E.E.; Landtwing, M.R.; Heinrich, C.A. Copper deposition by fluid cooling in intrusion-centered systems: New insights from the Bingham porphyry ore deposit, Utah. Geology 2004, 32, 217-220. [CrossRef]

26. Van den Kerkhof, A.M.; Hein, U.F. Fluid inclusion petrography. Lithos 2001, 55, 27-47. [CrossRef]

27. Klemm, L.M.; Pettke, T.; Heinrich, C.A.; Campos, E. Hydrothermal evolution of the El Teniente deposit, Chile: Porphyry Cu-Mo ore deposition from low-salinity magmatic fluids. Econ. Geol. 2007, 102, 1021-1045. [CrossRef]

28. Batkhishig, B.; Bignal, G.; Tsuchya, N. Hydrothermal quartz vein formation, revealed by coupled SEM-CL imaging and fluid inclusion microthermometry: Shuteen Complex, South Gobi, Mongolia. Resour. Geol. 2005, 55, 1-8. [CrossRef] 
29. Cooke, D.R.; Hollings, P.; Wilkinson, J.J.; Tosdal, R.M. Geochemistry of Porphyry Deposits. In Treatise on Geochemistry, 2nd ed.; Holland, H.D., Turekian, K.K., Eds.; Elsevier: Oxford, UK, 2014; Volume 13, pp. 357-381.

30. Rusk, B.G.; Reed, M.H.; Dilles, J.H. Fluid inclusion evidence for magmatic-hydrothermal fluid evolution in the porphyry copper-molybdenium deposit at Butte, Montana. Econ. Geol. 2008, 103, 307-334. [CrossRef]

31. Müller, A.; Herrington, R.; Armstrong, R.; Seltman, R.; Kirwin, D.J.; Stenina, N.G.; Kronz, A. Trace elements and cathodoluminesence of quartz in stockwork veins of Mongolian porpyhyry-style deposits. Miner. Depos. 2010, 45, 707-727. [CrossRef]

32. Bodnar, J.R.; Vityk, M.O. Interpretation of microthermometric data for $\mathrm{H}_{2} \mathrm{O}-\mathrm{NaCl}$ fluid inclusions. In Fluid Inclusions in Minerals: Methods and Applications; De Vivo, B., Frezzotti, M.L., Eds.; Virginia Technical Institute: Blacksburg, VA, USA, 1994; pp. 117-130.

33. Bodnar, R.J.; Lecumberri-Sanchez, P.; Moncada, D.; Steele-MacInnis, M. Fluid Inclusions in Hydrothermal Ore Deposits. In Treatise on Geochemistry, 2nd ed.; Holland, H.D., Turekian, K.K., Eds.; Elsevier: Oxford, UK, 2014; Volume 13, pp. 119-142.

34. Cooke, D.R.; Hollings, P.; Walsh, J.L. Giant porphyry deposits: Characteristics, distribution, and tectonic controls. Econ. Geol. 2005, 100, 801-818. [CrossRef]

35. Sillitoe, R.H. Porphyry copper systems. Econ. Geol. 2010, 105, 3-41. [CrossRef]

(C) 2020 by the authors. Licensee MDPI, Basel, Switzerland. This article is an open access article distributed under the terms and conditions of the Creative Commons Attribution (CC BY) license (http://creativecommons.org/licenses/by/4.0/). 